\title{
The Current Situation and Measures of Cross-Border E-Commerce in Cosmetics Industry: Case Study of Company ABL
}

\author{
Youxie Chen' ${ }^{1}$ Maner Wang', Yuang $\mathrm{Xu}^{3}$ \\ ${ }^{1}$ School of Management, Jinan University, Guangzhou, China \\ ${ }^{2}$ Rongshan Middle School, Foshan, China \\ ${ }^{3}$ Guangdong Nanyue Transportation Investment \& Construction Co., Ltd., Guangzhou, China \\ Email: chen_youxie@foxmail.com
}

How to cite this paper: Chen, Y.X., Wang, M.E. and Xu, Y.A. (2018) The Current Situation and Measures of Cross-Border E-Commerce in Cosmetics Industry: Case Study of Company ABL. Open Journal of Business and Management, 6, 265-278. https://doi.org/10.4236/ojbm.2018.62019

Received: March 14, 2018

Accepted: April 13, 2018

Published: April 16, 2018

Copyright $\odot 2018$ by authors and Scientific Research Publishing Inc. This work is licensed under the Creative Commons Attribution International License (CC BY 4.0).

http://creativecommons.org/licenses/by/4.0/

\begin{abstract}
Recent few years, shopping through the Cross-border E-commerce platforms has been so prevalent that they begin to play an important role in foreign trade. This paper would take the E-commerce company named $\mathrm{ABL}^{1}$ as our case, and analyse its macro-environment, the current situation and the development bottleneck. Based upon the research, we conclude that the environmental factor promoted the development of Cross-border E-commerce. However, problems such as homogeneous operation pattern between platforms and insufficient innovation exists. To survive from the severe competition, $\mathrm{ABL}$, the newly established company, has got to make the new strategic planning and start the brand marketing.
\end{abstract}

\section{Keywords}

Cross-Border E-Commerce, Foreign Trade, Network Economy, Brand Marketing

\section{Introduction}

\subsection{Industrial Background}

Cross-border E-commerce refers to the new type of export trade means by which companies and individuals use E-commerce to integrate the upstream, downstream, and related resources of the industry chain, and electronically display, negotiate and deal in traditional import and export trade [1]. Cross-border ${ }^{1}$ With the approval of the company's three managers, the full name of the company is replaced by $\mathrm{ABL}$ in this paper. 
E-commerce has the advantages of low threshold, few links, low cost, short cycle, etc., and it has been booming in the global scope [2] [3].

2013 is an important transition year for the Cross-border E-commerce industry in China, and in this year, the entire industry chain has undergone major changes in business models [4]. Since 2014, China's Cross-border E-commerce competition has become increasingly fierce. Each platform has also expanded its overall market size while competing with each other. In recent years, the annual growth rate of China's Cross-border E-commerce market has remained at around $30 \%$, and its share in foreign trade has increased year by year. The basic situation is shown in Figure 1.

In recent years, China's trade situation and Cross-border E-commerce industry have continued to expand, and the Chinese government has increased its efforts to support the traditional industry in the "Internet +" upgrade. In this context, we need to combine with the specific examples to explore the opportunities and challenges in the transformation and upgrading, as well as the response measures taken by company managers. In Guangzhou and other China cities, many small and medium-sized companies in traditional industries are experiencing the wave of transformation and upgrading. Some companies have achieved a successful transition, while others have been eliminated. We have selected ABL, a start-up Cross-border E-commerce cosmetics company, which has been successfully transformed and operating in good condition, as a case object because this company is representative in many aspects. Therefore, we hope to

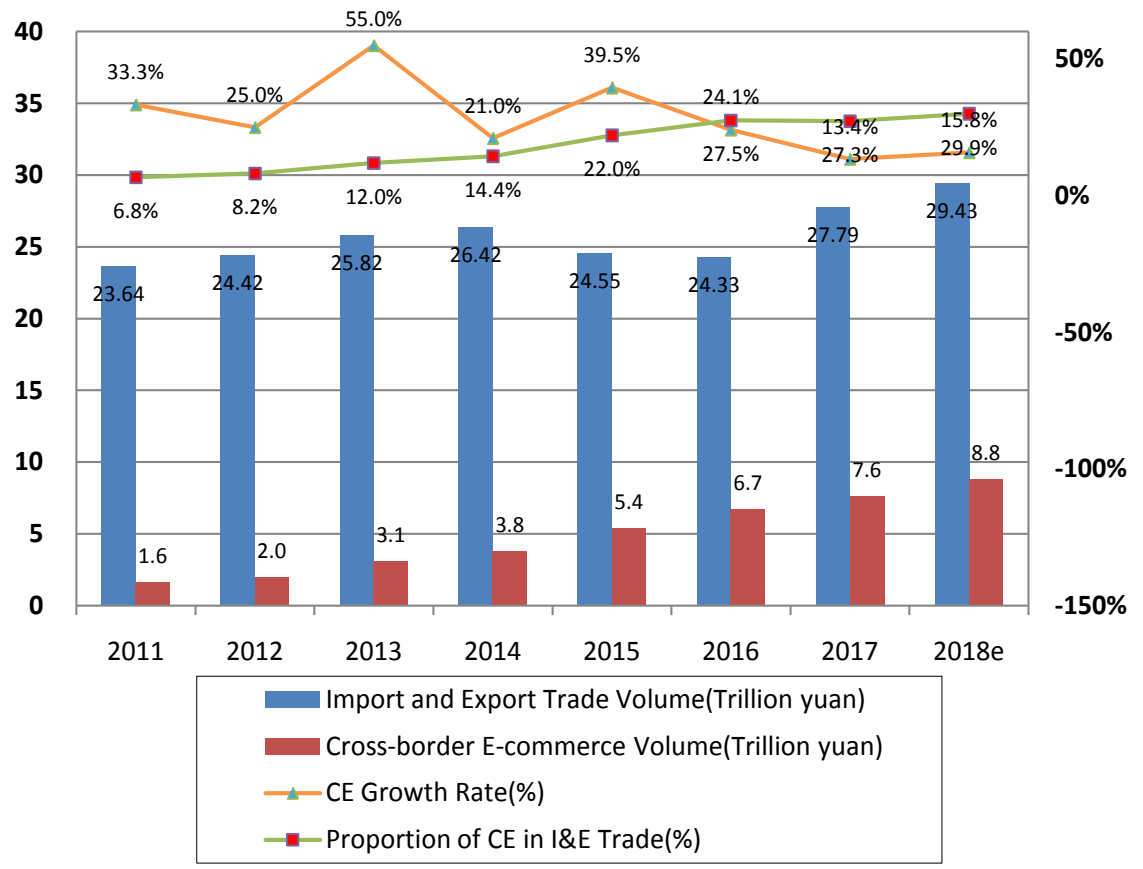

Figure 1. The Basic Situation of China's Foreign Trade and Cross-border E-commerce Market Transaction Size. Source: Ministry of Commerce of the People's Republic of China Official Website, http://data.mofcom.gov.cn/ Guangzhou IIMedia Consultation Group Official Website, http://www.iimedia.cn/ 
summarize the company's successful experience through case studies and provide development references for other similar companies in traditional industry.

\subsection{Literature Review}

In recent years, not only governments, companies, and consumers have paid great attention to the development of Cross-border E-commerce, academic researchers have also generated great interest in this field. Gomez-Herrera, Martens \& Turlea investigated the motivation and resistance of European Union Cross-border E-commerce trade through questionnaires [5]. However, the authors found that perfecting the law and optimizing the financial system may not necessarily promote the development of Cross-border E-commerce. Wang, Wang \& Lee study found that Cross-border E-commerce is conducive to promoting China's foreign trade, but the prerequisite is to reduce tariffs and transportation costs [6]. Wang et al. believe that the implementation of the policies introduced by the Chinese government is not in place and that the global economy shrinking is not conducive to the development of Cross-border E-commerce. In addition, the literature [7] [8] [9] also studied different issues related to Cross-border E-commerce.

Through literature review, it can be found that some scholars use a certain city in China as an example to analyze the Cross-border E-commerce enterprises in the city facing the external environment. Zhu \& Zhu analyzed the strengths, weaknesses, opportunities, and threats in the development of Cross-border E-commerce enterprises in Chongqing city and proposed development strategies from the perspective of the government, corporate, and online shopping platforms [10]. Wang \&He provided advice for the development of the Zhejiang Free Trade Zone, including suggestions for optimizing the customs supervision model and strengthening the training of talents [11].

The "PEST" model is a macro-environmental analysis tool commonly used in management research. The model analyzes the macro-environment of specific industries from the perspectives of "Political Environment", "Economical Environment", "Social Environment" and "Technical Environment" [12]. Zhang, $\mathrm{Wu}$, \& Zhu studied the environmental issues of Chinese Small and Medium-sized companies under the background of economic globalization, and they found that enterprises faced a similar external environment and proposed reform measures in supply chain management and human resources management [13]. In addition, literature [14] [15] also adopted the "PEST" framework for macro-environmental analysis. Therefore, the "PEST" model is a mature and valuable macro-environment analysis tool.

\subsection{Research Methods}

The research methods used in this paper include literature research method and case study method, and obtain ABL company's real information through in-depth interviews. In order to ensure the credibility of the research content, 
after display analysis conclusions to the company's managers initiatively, we revise and organize the paper based on their opinions.

We collect relevant literatures on "Cross-border E-commerce" and "Online Shopping" through the Internet. These literatures include Chinese and foreign journal articles. The literatures we collect are published in four years and we think that newly published papers can more truly reflect the development of the Cross-border E-commerce industry, and also help us collect more valuable information. Through literature research, we learned from the framework and content of other scholars in case studies, and also summarized the current macro-environment of China's Cross-border E-commerce industry, as shown in Section 2.

Because the second author of the paper knew the general manager of $\mathrm{ABL}$ company, we were fortunate enough to have an in-depth interview with the company's senior managers. The subject of the interview is the general manager, operations manager and marketing manager of ABL. These three managers are the founders of the company and are familiar with the company's situation. In December 2017, we conducted in-depth interviews with three managers in two separate occasions.

The first interview was with the general manager of ABL, Manager Wang. We mainly asked him about the company's macro situation. We have formulated 10 questions in advance, such as "Share the company's founding process and reasons?" and "How do you view the current macro environment of the Cross-border E-commerce industry? For example, policies, social and cultural aspects" and "How about the ABL's strategy positioning?" and other issues. During the interview, we requested Manager Wang to answer in detail what is not clear for us.

The second interview was with the company's operations manager, Manager Zhen, and marketing manager, Manager Ou. Although we interviewed two managers at the same time, we have different concerns for them. For Manager Zhen, we mainly learn from him about the company's supply chain management, product quality controlling, and IT supporting. And we mainly understand the product sales situation and promotion of the company's popularity through Manager Ou.

Two detail need to be emphasized: First, we ask three managers to combine their own business and share their judgments about the future development of the company. Second, we have recorded the contents of the interviews so that we can be summed up later.

Based on the in-depth interviews with three managers of ABL company and the review of the literature, this paper profoundly analyzes the macro-environment of the Cross-border E-commerce industry and the company's operating model, and proposes targeted development strategies related to the key issues in the company's development process. Based on the analysis conclusions, it provides reference for the operation and development of other start-up 
Cross-border E-commerce cosmetics companies.

\section{Macro-Environment Analysis}

This research paper applies PEST theory to analyze the macro environment, and the analysis points are summarized as shown in Figure 2. We believe that the macro environment has both development opportunities and risks which are relative and temporary, and the company can still use the appropriate strategies to transform risks into opportunities.

Firstly, the POLITICAL environment. In recent years, the Chinese government has attached great importance to the development of Cross-border E-commerce and actively guided enterprises to develop Cross-border E-commerce business and created a favorable policy environment for Cross-border E-commerce companies [16]. In September 2013, Guangzhou was approved as the sixth pilot city for cross-border business import services. This has created a convenient environment for the development of local Cross-border E-commerce imported company in Guangzhou. In 2014 and 2015, several government departments launched multiple specific projects to facilitate cross-border trade, which have accelerated the development of Cross-border E-commerce industry. Although the government has actively promoted a number of related policies and measures to support the development of Cross-border E-commerce, there are still difficulties in the management of customs services, intellectual property, etc., which has restricted the development of Cross-border E-commerce to a certain extent [17]. In addition, there is a diversification of government policy objectives, namely, the lack of coordination among different policies and purposes, resulting in the cancellation of policy positive effects [18].

Secondly, the ECONOMIC environment. Although the growth of China's GDP has slowed in recent years, the per capita GDP and disposable income of urban residents are still on the upward trend. The basic situation is shown in

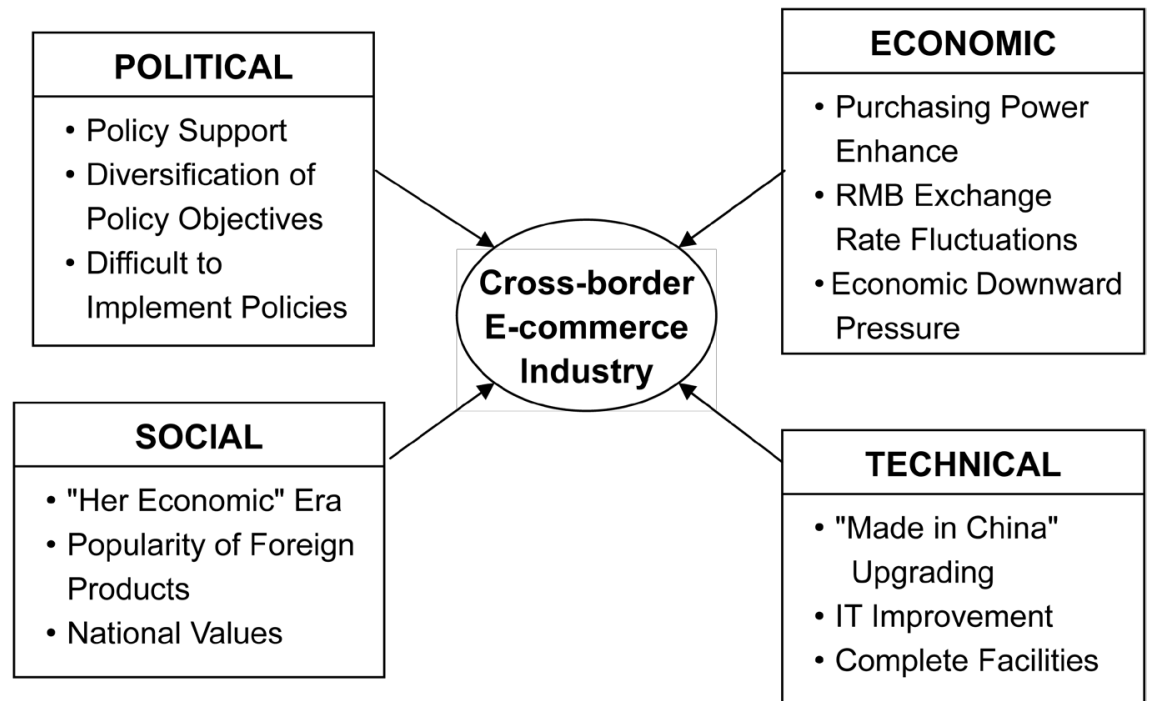

Figure 2. Summary of PEST Analysis Source: According to the Literature Review. 
Table 1. The per capita disposable income of Chinese residents has steadily increased, laying the foundation for the prosperity and development of the online shopping market. Moreover, new forms of online shopping, such as cross-border shopping, have strong potential for development and play an important role in stimulating economic growth [6]. Since the second half of 2015, the continuous devaluation of the RMB has curbed imported cross-border shopping, but the sensitivity of individual consumers' cross-border online shopping behavior to exchange rate fluctuations is not obvious, and the scale of Cross-border E-commerce g transactions continues to climb [7]. However, China's economic development is facing downward pressure and the new economic normal. It is both a challenge and an opportunity for the newly established Cross-border E-commerce cosmetics ABL company.

Thirdly, the SOCIAL environment. Chinese female groups have become the most active consumers of E-commerce shopping. They are an important force in promoting the development of the E-commerce industry. Cosmetics, clothing, etc. are the most important product categories for women online shopping [19] [20]. The consumption habits of Chinese female consumers gradually tend to be individualized and diversified, and cross-border shopping through informal channels is prone to problems of poor quality and difficulty in returning goods. This has created development opportunities for ABL and other professional Cross-border E-commerce cosmetics companies. However, the development of Cross-border E-commerce is vulnerable to the impact of national values and the trend of relations with other countries, such as the fact that territorial disputes intensify resistance to the exclusion of a country's goods. It is undeniable that the concept of cross-border shopping among Chinese consumers is still immature and still needs to be cultivated, which will put pressure on the capital and market development of the start-up Cross-border E-commerce company [17].

Fourth, the TECHNICAL environment. Cross-border E-commerce has promoted the transformation and upgrading of "Made in China". After years of innovation and development, E-commerce trade in China has gradually formed a

Table 1. Statistics of China's GDP and Disposable Income of Urban Residents over the Years.

\begin{tabular}{ccccc}
\hline Year & $\begin{array}{c}\text { GDP } \\
\text { (Billion yuan) }\end{array}$ & $\begin{array}{c}\text { Growth Rate } \\
(\%)\end{array}$ & $\begin{array}{c}\text { GDP per Capita } \\
\text { (yuan) }\end{array}$ & $\begin{array}{c}\text { Urban per Capita } \\
\text { Disposable Income (yuan) }\end{array}$ \\
\hline 2011 & 489,301 & 9.5 & 36,403 & 21,810 \\
2012 & 540,367 & 7.9 & 40,007 & 24,565 \\
2013 & 595,244 & 7.8 & 43,852 & 26,955 \\
2014 & 643,974 & 7.3 & 47,203 & 28,844 \\
2015 & 689,052 & 6.9 & 50,251 & 31,195 \\
2016 & 743,585 & 6.7 & 53,980 & 33,616 \\
2017 & 827,122 & 6.9 & 59,660 & 36,396 \\
\hline
\end{tabular}

Source: According to the Statistics Released by the National Bureau of Statistics of the People's of China, http://www.stats.gov.cn/tisj/ 
smooth and simple supply chain with corresponding technologies in the areas of trade, logistics, service and financing, and the technologies have been the leading international level [21]. However, technologies such as payment and logistics still need to be further optimized. The current payment technology is still difficult to take into account both safety and convenience. In particular, there are still security risks when selecting foreign websites for cross-border online shopping. In terms of logistics technology, China's logistics companies engaged in Cross-border E-commerce have some unpleasant problems, such as slow transportation and low service levels [22].

\section{ABL Company Analysis}

\subsection{Company Basic Situation}

Founded in January 2015, ABL is a Cross-border E-commerce company dedicated to the sale of foreign high quality imported cosmetics through online and offline channels. The company's parent company is Guangzhou Donghong Mobile Media Technology Limited Company, and Donghong's main business is mobile information technology services and it has been identified as a high-tech enterprise by government. The ABL company operations manager showed us the company's operational data, including the number of core users, the number of WeChat public number fans, and operating revenue. The website platform operated by ABL company has accumulated close to 50,000 core users. The company's WeChat public number has more than 400,000 fans, and its monthly turnover is close to 6 million yuan, with a gross margin of approximately $30 \%$. The operations manager believes that these data can reflect the company's development potential. At the same time, ABL has established service departments such as marketing, customer service, and beauty specialists, and rely on its parent company to provide information technology to support the operation and management of downstream agents.

The mission of ABL company is to create beauty and self-confidence for women, and its strategic positioning is "Internet + Traditional Distribution and Services", that is, the use of the Internet to introduce foreign top cosmetic brands to China, and online and offline sales. ABL analyzes internal and external factors, and targets its target consumer groups as high-income women, providing these consumers with safe, reliable and world-class beauty products. ABL three managers believe that the market positioning focusing on high-income women is in line with the company's mission and strategic positioning, but also to ensure the profit of product sales.

\subsection{Product Analysis}

In actual operation, $\mathrm{ABL}$ is mainly responsible for the brand operation, sales, and customer service of foreign high-end cosmetics. Currently, the company has signed exclusive agency agreements with 47 internationally renowned cosmetics brands in Japan, South Korea and Australia, and the exclusive agency period is 7 
years, such as Bb LABORATORIES, the pioneer of the placenta extract solution, and RISOU, the winner of Monde selection that is the highest award in the cosmetics field.

Unlike most Cross-border E-commerce cosmetic platforms, the brands that ABL companies represent are relatively low-profile in the country but highly recognized abroad. And in order to ensure the quality of branded products, ABL sets strict selection criteria to determine the cooperation of brand dealers. ABL's selection criteria are shown in Figure 3.

The managers introduced the meaning of the three criteria. For "Sizable Sales", this requires that the product be ranked in the top 10 in terms of sales of the same type of product in the country of origin. The "Award" dimension requires the product or brand to be awarded in the field of international cosmetics. The "Product History" dimension requires the brand to have a sales life of 10 years or more. The three managers all emphasized that ABL company would sell the products as an agent only if these three criteria are met at the same time. This will help ensure the quality, safety and reliability of the products.

We believe that the advantages and disadvantages of the cosmetics brands sold by ABL company coexist. Although such brands are conducive to product differentiation with other Cross-border E-commerce cosmetics platforms to a certain extent, reduce competition, and enjoy higher profit margins, they need to work even harder to cultivate consumer purchase intentions and awareness. This is an important issue that the newly established E-commerce platform needs to break through.

\subsection{Operational Status Analysis}

$\mathrm{ABL}$ is focused on creating a dual channels E-commerce platform. It not only realizes online management of suppliers, warehouses, logistics, e-commerce platforms, and consumers through the use of information technology, but also builds offline experience stores as traditional distribution channels to provide services and support for customers. The online channels mainly include PC-side shopping websites and WeChat service numbers, as well as Tmall.com International and JD.com Global, for the purpose of sales expansion. Offline channels include both traditional distribution channels and product experience stores. At

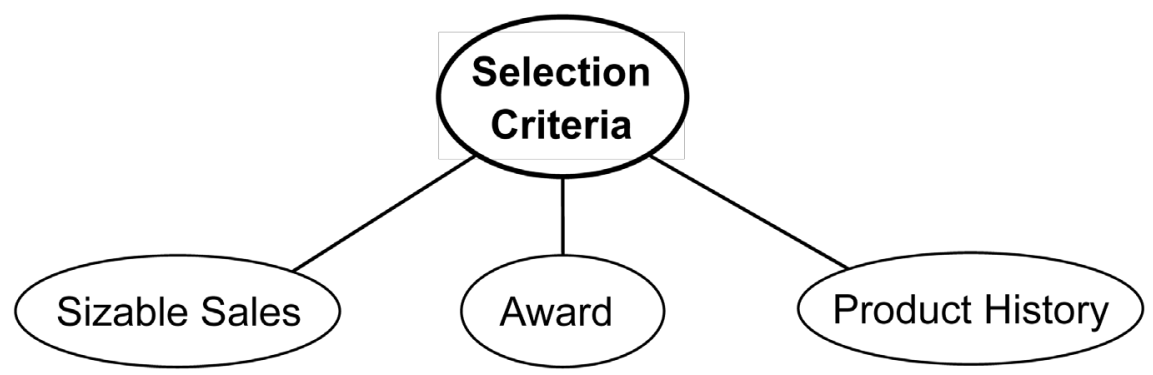

Figure 3. ABL Company Selection Criteria. Source: According to the Content of the Interview. 
present, ABL company has experience shops in first-tier cities such as Shanghai, Guangzhou, and Beijing to facilitate consumers to experience their products, so as to promote online sales, improve consumer awareness, and foster customer loyalty. Three managers all stated that the practice of opening an offline experience shop did increase the likelihood of consumers buying back. In terms of traditional distribution and services, $\mathrm{ABL}$ has set up third-tier offline agents. The first-level agents are mainly responsible for the development and management of lower-level agents within the four major regions of the country, including East China, Southern, Northern and Western regions. Offline agents can flexibly adjust the retail price according to the scope of change agreed in the contract. Currently offline sales channels include shopping mall counters, cosmetics stores, beauty salons, and individual direct sales. The ABL company also uses advertising and public relations for product marketing. The advertising aspect includes optimizing the search engine and holding product brand recommendation meetings. For the public relations, it is mainly through news media coverage to increase the visibility of platforms and product brands. At present, we can also find the news reports on the Internet, and the content is about the entrepreneurial experience of the three founders of $\mathrm{ABL}$.

We consist that ABL's sales through dual channels will help to quickly expand market share and maximize customer satisfaction. In addition, PR marketing and non-discounted pricing are beneficial to maintaining a high-quality image of the product. A variety of operational strategies are coordinated with each other to adapt to the current development requirements of the ABL company.

\subsection{Comparative Analysis}

According to the online public information and interview results, we conducted a comparative analysis of ABL company and two other start-up Cross-border E-commerce cosmetics companies. The results are shown in Table 2.

Through comparative analysis, we can find that ABL company is similar to the other two companies in many aspects such as operation mode and logistics and distribution. The biggest difference is the product brand philosophy and company positioning. The products that ABL Company sells have the characteristics of low domestic recognition, yet high degree of foreign reputation, and reliable quality. The three managers positioned ABL company as a "Foreign High-quality Cosmetic Brand Agent". The core work of the company was brand introduction and brand marketing. At the same time, ABL company uses the online platform for brand promotion, sub-agent management, and the use of offline experience stores to strengthen contact with customers and support sales activities of subordinate agents.

\section{Development Dilemma Analysis and Suggestions}

\subsection{Analysis of Development Dilemma}

Through the analysis of the macro environment and company situation, we 
Table 2. Comparative Analysis of Three Cross-border E-commerce Cosmetics Companies.

\begin{tabular}{|c|c|c|c|}
\hline & BeBeauty & VMEI & $\mathrm{ABL}$ \\
\hline Channel & $\begin{array}{l}1 \text { Offline Experience } \\
2 \text { Online Consumption }\end{array}$ & $\begin{array}{c}1 \text { Counter Sales } \\
2 \text { Online Consumption }\end{array}$ & $\begin{array}{l}1 \text { Offline Experience } \\
2 \text { Online consumption }\end{array}$ \\
\hline Logistics & $\begin{array}{c}1 \text { Warehousing in Free } \\
\text { Trade Zone } \\
2 \text { Direct Express }\end{array}$ & $\begin{array}{l}1 \text { Warehousing in Hong Kong } \\
2 \text { Warehousing in Bonded Area } \\
3 \text { Direct Express }\end{array}$ & $\begin{array}{l}1 \text { Warehousing in Overseas } \\
2 \text { Direct Express }\end{array}$ \\
\hline Purchase & $\begin{array}{l}1 \text { Exclusive Agent } \\
2 \text { Cooperation with } \\
\text { Manufacturers }\end{array}$ & $\begin{array}{c}1 \text { Exclusive Agent } \\
2 \text { Hong Kong Shopping Mall } \\
\text { Counters }\end{array}$ & Exclusive Agent \\
\hline Brand Features & High Cost Performance & $\begin{array}{l}1 \text { First-line Famous Brands } \\
2 \text { Second-line brand }\end{array}$ & $\begin{array}{c}1 \text { Low Domestic } \\
\text { Recognition } \\
2 \text { High Degree of Foreign } \\
\text { Reputation }\end{array}$ \\
\hline $\begin{array}{l}\text { Company } \\
\text { Positioning }\end{array}$ & $\begin{array}{l}1 \text { CE Cosmetics } \\
\text { Companies } \\
2 \text { O2O Operator }\end{array}$ & Online Shopping Mall & $\begin{array}{l}\text { Foreign High-quality } \\
\text { Cosmetic Brand Agent }\end{array}$ \\
\hline $\begin{array}{c}\text { Target } \\
\text { Customers }\end{array}$ & $\begin{array}{c}1 \text { Post 90s Girls } \\
2 \text { Favor Japanese and } \\
\text { Korean Taiwanese Style }\end{array}$ & $\begin{array}{l}1 \text { Female of All Ages } \\
2 \text { Young Male }\end{array}$ & $\begin{array}{c}\text { Middle-aged \& } \\
\text { High-income Female }\end{array}$ \\
\hline
\end{tabular}

Source: According to the Information Released by the Official Website and some Media Reports, https://www.bebeauty.cc/ https://www.vmei.com/ http://www.aimbeauty.cn/

https://www.iyiou.com/p/35396

believe that although the current macro environment has many favorable factors for the development of ABL company, compared to other related platforms, the newly established ABL company has no absolute advantage in Cross-border E-commerce operations. Just as three managers said: "Companies have to compete with competitors for market share". In addition, the brands of product with low domestic reputation, platform operating mode and sales channels and other aspects of lack of innovation, it is difficult to form a lasting competitiveness. Finally, ABL company has the unfavorable factors such as short operating time and limited funds on the E-commerce platform. These factors will restrict the further development of the company.

In conclusion, we believe that the biggest bottleneck in the current ABL Cross-border E-commerce company's development is that domestic consumers have low awareness of the product brand. Only with proper development strategy planning and implementation can ABL break through this bottleneck and achieve long-term development.

\subsection{Development Strategic Planning}

Based on the analysis of the macro-environment, company situation, and development dilemma, the authors believes that ABL company should carry out long-term planning for its development strategy, which can be summarized as a "three-step strategy", as shown in Figure 4. 


\section{STEP-1: Within 1-2 years}

Balancing Development of Dual Channels, Focusing on Brand Awareness

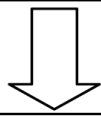

STEP-2: Within 3-5 years

Focusing on the Development of Online Channels, Strengthening the ABL's Brand Value, Optimizing Product Brand Composition

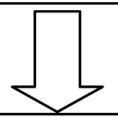

STEP-3: Within 6-8 years

Narrowing down the offline market, Integrating Online Channels, Establishing Cooperation with International Well-known Cosmetics brands

Figure 4. ABL's Long-term Strategic Plan. Source: According to the Content of the Interview.

Within 1 - 2 years, ABL company has mature offline sales channels, but online sales channels have more potential for development. Therefore, we believe that at this stage, $A B L$ should take into account both online and offline channels, which can ensure a stable source of profits and lay a foundation for the long-term development of the company. On the other hand, we believe that the company should focus on improving product brand awareness, expand consumer contact with products, and enhance consumers' experience with products.

Within 3 - 5 years, the company should focus on the development and improvement of online sales channels, gradually channeling offline consumers to online consumption, and nurturing consumers' online spending habits. At the same time, the company also needs to deepen the brand value of the E-commerce platform, optimize the product brand, and eliminate cosmetics brands with low customer acceptance and poor experience. It cannot be overlooked that ABL must also enrich the forms of offline services and optimize the quality of services.

Within $6-8$ years, ABL should gradually reduce the offline sales share and fully integrate all online sales channels. On the basis of maintaining the market share of the original agency brand, the company needs to gradually establish a cooperative relationship with the international mainstream well-known cosmetics brands, forming an integrated professional Cross-border E-commerce cosmetics company with multiple product categories and high customer service value.

\subsection{Development Strategy Advice}

Combined with the development of strategic planning, we believe that the current ABL company is in a crucial period of advancing the first stage strategy. At present, the company's core work of development is to increase brand awareness 
through multiple marketing methods. Here, apply the brand marketing $4 \mathrm{P}$ theory to give the advices.

First of all, in terms of PRICE, ABL company can use the pricing method of rouge or prestige pricing to maintain the brand's high-value image, ensure profit margins and obtain huge profits. Secondly, in terms of PRODUCT, the company needs to further improve the official website's information on product and brand introductions, funnel the currently-cooperated brands, and promote marketing of brands with high sales, recognition, and customer loyalty. Thirdly, in terms of PLACE, the company can open offline experience stores through joining to reduce capital investment, expand sales through emerging channels such as plastic hospitals and rebate networks, like Fanli.com, and also need to develop detailed contracts to coordinate online and offline dual channels. Finally, in terms of PROMOTION, ABL can add entries in Baidu and other search engines to facilitate customer inquiries about product brand information. ABL company should also organize beauty knowledge sharing sessions and community activities to increase consumer awareness of the brand, and can also use WeChat account number and new Internet media such as webcast platforms to promote the sales of products.

\section{Conclusions}

At present, Cross-border E-commerce development is in good shape and the overall macro environment is conducive to the development of the Cross-border E-commerce industry. There are individual unfavorable factors that can be avoided through reform and innovation. Through research, it can be found that the existing professional Cross-border E-commerce cosmetics company has the phenomenon of homogenization of operation mode, lack of innovation and so on. We selected ABL, a start-up Cross-border E-commerce cosmetics company, to conduct a case study. The company has maintained a steady growth from its establishment through the differentiation of product brands and company positioning, combined with online and offline dual channels. However, ABL company is facing a development bottleneck with low product brand recognition. We believe that companies should carry out long-term strategic planning and implement appropriate marketing activities to win in fierce competition.

The Internet has played a positive role in promoting the development of traditional industries, but different companies or industries have their inherent development rules. Therefore, our view is that companies should not blindly follow the trend in the process of Internet-related reforms, but should focus on outstanding issues facing corporate development based on adequate environmental analysis and analysis of their own strengths and weaknesses, and formulate sound development strategies to deal with risks and challenges.

\section{References}

[1] Ma, S.Z. and Chen, A.J. (2017) Cross-Border E-Commence: B2B or B2C-Based on the Perspective of Marketing Channel. Journal of International Trade, No. 3, 75-86. 
[2] Lai, Y.W. and Wang, K.Q. (2014) Cross-Border Electronic Commerce's Development Characteristics, Obstacle Factors and the Next Step in China. Reform, No. 5, 68-74.

[3] Feng, L.P., Ma, J., Wang, Y. and Yang, J. (2017) Supply Chain Downstream Strategic Cost Evaluation Using L-COPRAS Method in Cross-border E-commerce. International Journal of Computational Intelligence Systems, 10, 815-823. https://doi.org/10.2991/ijcis.2017.10.1.54

[4] Guo, H.L. (2017) On the Countermeasures of Cross-Border E-Commerce Development from the Angel of Industrial Clusters. China Business and Market, 31, 55-65.

[5] Gomez-Herrera, E., Martens, B. and Turlea, G. (2014) The Drivers and Impediments for Cross-Border E-Commerce in the EU. Information Economics \& Policy, 28, 83-96. https://doi.org/10.1016/j.infoecopol.2014.05.002

[6] Wang, Y., Wang, Y. and Lee, S.H. (2017) The Effect of Cross-Border E-Commerce on China's International Trade: An Empirical Study Based on Transaction Cost Analysis. Sustainability, 9, 2028-2041. https://doi.org/10.3390/su9112028

[7] Deng, Z. and Wang, Z. (2016) Early-Mover Advantages at Cross-Border Business-to-Business E-Commerce Portals. Journal of Business Research, 69, 6002-6011. https://doi.org/10.1016/j.jbusres.2016.05.015

[8] Giuffrida, M., Mangiaracina, R., Perego, A. and Tumino, A. (2017) Cross Border B2C E-Commerce to Greater China and the Role of Logistics: A Literature Review. International Journal of Physical Distribution \& Logistics Management, 47, 772-795. https://doi.org/10.1108/IJPDLM-08-2016-0241

[9] Kim, T.Y., Dekker, R. and Heij, C. (2017) Cross-Border Electronic Commerce: Distance Effects and Express Delivery in European Union Markets. International Journal of Electronic Commerce, 21, 184-218. https://doi.org/10.1080/10864415.2016.1234283

[10] Zhu, Q.S. and Zhu, H.T. (2016) The SWOT Analysis of the Development of Cross-Border E-Commerce in Chongqing under the Background of Internet Plus-Taking Chongqing as an Example. Journal of Sichuan University of Science \& Engineering (Social Sciences Edition), 31, 73-82.

[11] Wang, G.B. and He, W. (2018) Strategic Research on the Development of Cross-Border E-Commerce under the Context of Free Trade Zone-Taken Example of Zhejiang Free Trade Zone. Prices Monthly, No. 2, 57-60.

[12] Zhao, X.Y., Zhang, M.H. and Ma, J.Z. (2015) Exploration of the Development and Management of China's Natural Reserves Based on PEST Model. Issues of Forestry Economics, 35, 272-283.

[13] Zhang, G.Q., Wu, H.Y. and Zhu, S.Y. (2016) The Research of Small and Medium-Sized Enterprises Environment Under Globalizations-Based on the PEST Framework. Reformation \& Strategy, 32, No. 5.

[14] Wang, A.W. (2015) Study on the Status Quo, Influencing Factors of E-Commerce Service Industry and Its Countermeasure. Prices Monthly, No. 6, 41-44.

[15] Zhang, H. (2011) Research on the Development of China's Cultural Trade Based on PEST Analysis. Asia-Pacific Economic Review, No. 1, 69-73.

[16] Wei, P.Q. (2017) Countermeasures for the Development of Cross-Border E-Commerce with the Strategic Benefits Brought by the Belt and Road Initiative. China Business and Market, 31, 62-70.

[17] Hu, R., Gao, X. and Zhi, H.B. (2017) Cross Boarder E-Commerce Customs Risk 
Control Based on Bayes Network. Systems Engineering, 35, 115-121.

[18] Chen, N. and Yang, J.Z. (2017) Mechanism of Government Policies in Cross-Border E-Commerce on Firm Performance and Implications on M-Commerce. International Journal of Mobile Communications, 15, 69-84. https://doi.org/10.1504/IJMC.2017.080578

[19] Li, W.M. and Lu, F.Y. (2015) Development Trends of Female Economy and Measures for Its Further Development. Journal of Yunnan Minzu University (Social Sciences), 32, 66-74.

[20] Wu, W.Y., Quyen, P.T.P. and Rivas, A.A.A. (2017) How E-Services Capes Affect Customer Online Shopping Intention: The Moderating Effects of Gender and Online Purchasing Experience. Information Systems and E-Business Management, 15, 689-715. https://doi.org/10.1007/s10257-016-0323-x

[21] Du, Y.H. (2016) Research on the Development Strategy of Cross-Border E-Commerce Based on the Background of "The Belt and Road". Reform of Economic System, 6, 66-70.

[22] Pang, Y. (2015) Research on International Logistics Operation Mode under the Environment of Cross-Border E-Business. China Business and Market, 10, 15-20. 